\title{
導電性高分子系太陽電池のキャリア発生と発電機構 に関する検討
}

\author{
中村潤之介 ${ }^{\mathrm{a}}$, 原岡 壮馬 ${ }^{\mathrm{a}}$, 成島 和男 ${ }^{\mathrm{b}}$ \\ a 宇部高専専攻科生産システム工学専攻，₹755-8555 山口県宇部市常盤台 2-14-1 \\ b宇部高専電気工学科, $\overline{7} 755-8555$ 山口県宇部市常盤台 2-14-1 \\ e-mail:narushim@ube-k.ac.jp
}

(Received: January 8, 2021; Accepted for publication: February 8, 2021; Online publication: May 7, 2021)

Organic solar cells are flexible elements that offer benefits such as low cost, light weight, and applicability. For this study, quantum chemistry calculations of cells using conductive polymers were performed. Poly (3,4-ethylenedioxythiophene)-poly (styrenesulfonate)(PEDOT:PSS), phthalocyanine and fullerene $\mathrm{C}_{60}$ were used as semiconductors. Generation of carriers (conduction electrons and holes) was expected in both the ground state and the excited state. When MgAg and $\mathrm{Al}$ were selected for the electrodes, the energy diagram was found to have an ideal step structure. The organic solar cell was designed from the energy diagram of the whole layer that constituted the solar cell.

Keyword: Organic solar cells, Conductive polymer, Quantum chemistry calculations, Generation of carriers, Energy diagram

\section{1 はじめに}

有機太陽電池は無機系と比べ，低コスト，軽量，塗 布可能性等の特徴を併せ持つフレキシブル素子である [1-6]. 平本氏は, 有機太陽電池の根本的な特徵と動作 原理を説明し，フラーレン $\mathrm{C}_{60}$ を用いた太陽電池の光電 変換効率を上げるための工夫について言及している [1]. T. T. T Luong等はフタロシアニンと $\mathrm{C}_{60}$ を用いた太陽電 池を作製し，変換効率を測定している [2]. 導電性高分 子を用いた有機太陽電池は, 変換効率が比較的高く, 盛 んに研究されている [3-6]. Meng等はフラーレン $\mathrm{C}_{70}$ 誘 導体と導電性高分子を用いたタンデム構造を持つ太陽電 池を作製した。これは，高い変換効率 $17.3 \%$ を持つ [4]. しかし, フラーレン誘導体は高価であり, 特に $\mathrm{C}_{70}$ 誘導 体となると極めて高価となる.

本研究では比較的安価な $\mathrm{C}_{60}$ を用い, また, 水系で利用 でき, 環境にもやさしいPoly (3,4-ethylenedioxythiophene)poly (styrenesulfonate)(PEDOT:PSS)を用いた太陽電池を設 計を計算化学から検討することを目的とする. 具体的に は, 有機太陽電池素子内の光電変換層内における伝導電 子と正孔の発生の有無を調べ，素子全体のエネルギーダ
イアグラムを考案し．素子構造を検討することを目的と する.

\section{2 計算方法}

計算には，Gaussian09 (Gaussian, Inc.)を用いた。構造 最適化計算は計算コストの関係のため, Hartree - Fock法 (HF 法)を選択した。基底関数は 6-31G (d) とした. p型 としてPEDOT:PSS，n型としてフラーレン $\left(\mathrm{C}_{60}\right)$ を横並 びに配置し, 基底状態の構造最適化及び励起計算(TD$\mathrm{HF})$ を行った。 励起状態は最低限の一電子励起を用い た.PEDOT:PSS は計算資源の都合上，モノマー構造を採 用した．分子間距離は本研究の比較対象とした「フタロ シアニン類及び $\mathrm{C}_{60}$ からなる系」 [7] と比較・検討を行う ために約 $24 \AA$ とした。 この $24 \AA$ は，フタロシアニン結晶 単位胞のc 軸の長さに相当している。電荷密度分布には Mulliken 法を用いた。 


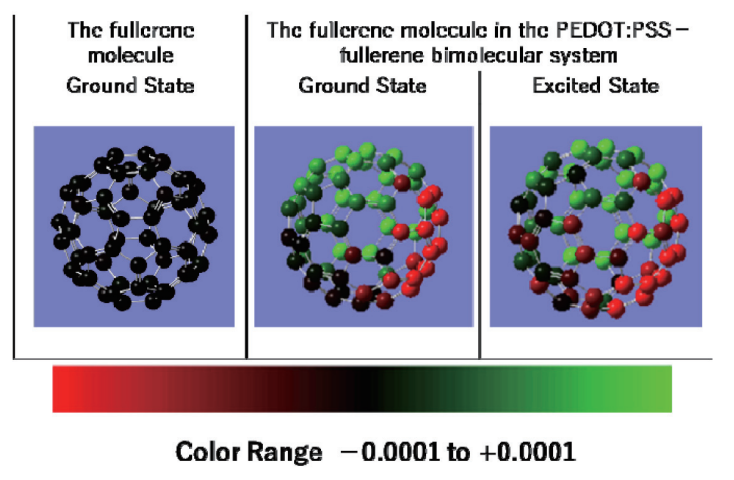

Figure 1. Charge density distribution in the $\mathrm{C}_{60}$ molecule and the PEDOT:PSS-C 60 system

\section{3 結果と考察}

\section{1 伝導電子と正孔の発生}

Figure 1 は, 左から $\mathrm{C}_{60}$ 単分子における基底状態の電荷 密度, PEDOT:PSS と $\mathrm{C}_{60}$ から構成される系における基底 状態, 並びに励起状態の電荷密度分布である. $\mathrm{C}_{60}$ 単分 子における基底状態では, 電荷はほとんど存在しない. PEDOT:PSS とC60 から構成される系においては, $\mathrm{C}_{60}$ の 右側にPEDOT，さらに右側にPSSを配置している．この 様子は Figure 2 に示す. 基底状態では PEDOT:PSSに近い 側は負に帯電している.

Figure 1 は, 伝導電子が, 基底状態(実測系では非照射 時の暗状態に相当)においても発生していることを意味 している. 従って対となる正孔も PEDOT:PSSに存在す ることが確信できる. 暗状態における伝導電子や正孔の 存在が有機太陽電池に好ましい影響を与えることはすで に明らかになっている。 [8]

一方，励起状態(実測系では照射時の明状態に相当)の 電荷密度分布は, 基底状態に比べて, さらに変化が見ら れた. PEDOT-PSS (p型)と $\mathrm{C}_{60}(\mathrm{n}$ 型) 間の界面接合型の太 陽電池を作製したところ, 電極面積 $0.5 \mathrm{~cm}^{2}$ において, 0.5 $\mu \mathrm{A}$ 程度の光電流が得られた. 光照射により, 伝導電子 が価電子帯から伝導帯に遷移している証拠となる. 以上 より PEDOT:PSS と $\mathrm{C}_{60}$ は, 太陽電池の材料として適して いることが分かった.

\section{2 エネルギーダイアグラム}

有機太陽電池素子は, 一般に正孔輸送層, バルクへテ 口の光活性層, 電子輸送層を持っており, これらを二つ の電極で挟む構造となっている. PEDOT:PSS と $\mathrm{C}_{60}$ を用 いた太陽電池のエネルギーダイアグラムを作成した結 果, 伝導電子と正孔の流れに障壁があることが分かっ

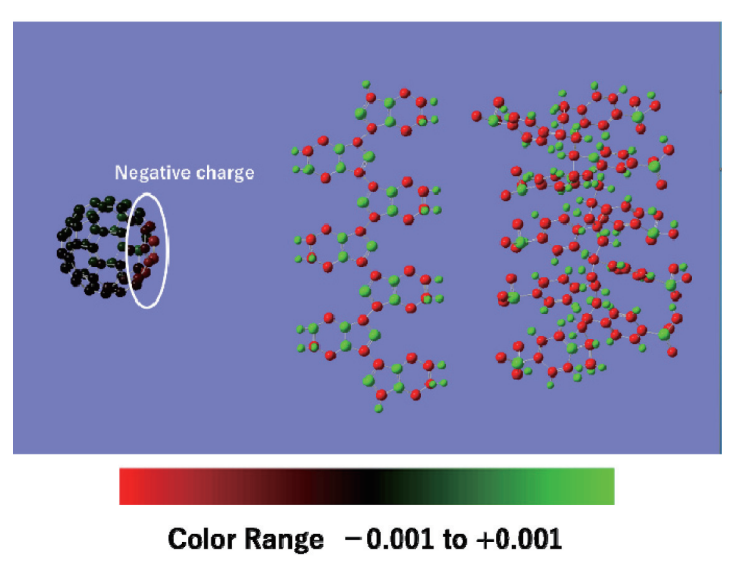

Figure 2. Ground state charge density distribution in the PEDOT:PSS-C 60 system

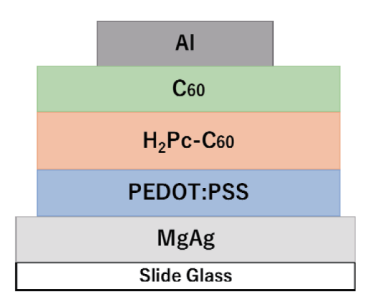

Figure 3. Structure of organic solar cell

た.

フタロシアニン $\mathrm{H}_{2} \mathrm{Pc}$ と $\mathrm{C}_{60}$ 系の電子物性を量子化学計 算より考察した文献がある. [7, 9, 10]. この系の基底状 態では, 本研究と同様に伝導電子生じることが明らかと なっている $[7,9]$. 文献9では, 正孔の発生も明確に見ら れた. 励起状態では, 発生した電子状態の変化もはっき りと得られている [10]. 光電変換層には, $\mathrm{H}_{2} \mathrm{Pc}-\mathrm{C}_{60}$ 系の 方がより適していると我々は考えた.

なお, PEDOT:PSS と $\mathrm{C}_{60}$ には, 3.1 節に述べた考察から, 光電変換層と正孔輸送層(PEDOT:PSS)の間において, 光 電流の発生も期待できる.さらに, フタロシアニンとは 異なる波長の光も吸収でき, 吸収帯域が拡がる.

我々が考案した有機太陽電池の構造を Figure 3 に, エ ネルギーダイアグラムを Figure 4 に示す。電極は $\mathrm{MgAg}$ と $\mathrm{Al}$ を採用した。

バルクヘテロ層 $\left(\mathrm{H}_{2} \mathrm{Pc}-\mathrm{C}_{60}\right.$ 層)が主たる光電変換層とな る. 光が照射されると電子が励起し, 伝導電子と正孔が Figure 4のように生じる. また, 一部は光電変換層と正 孔輸送層(PEDOT:PSS) 間に生じる. Figure 4中では, 伝 導電子が黒丸, 正孔が白丸で表している. 伝導電子と正 孔は, それぞれ青矢印と赤矢印のように電極へ流れ, 電 


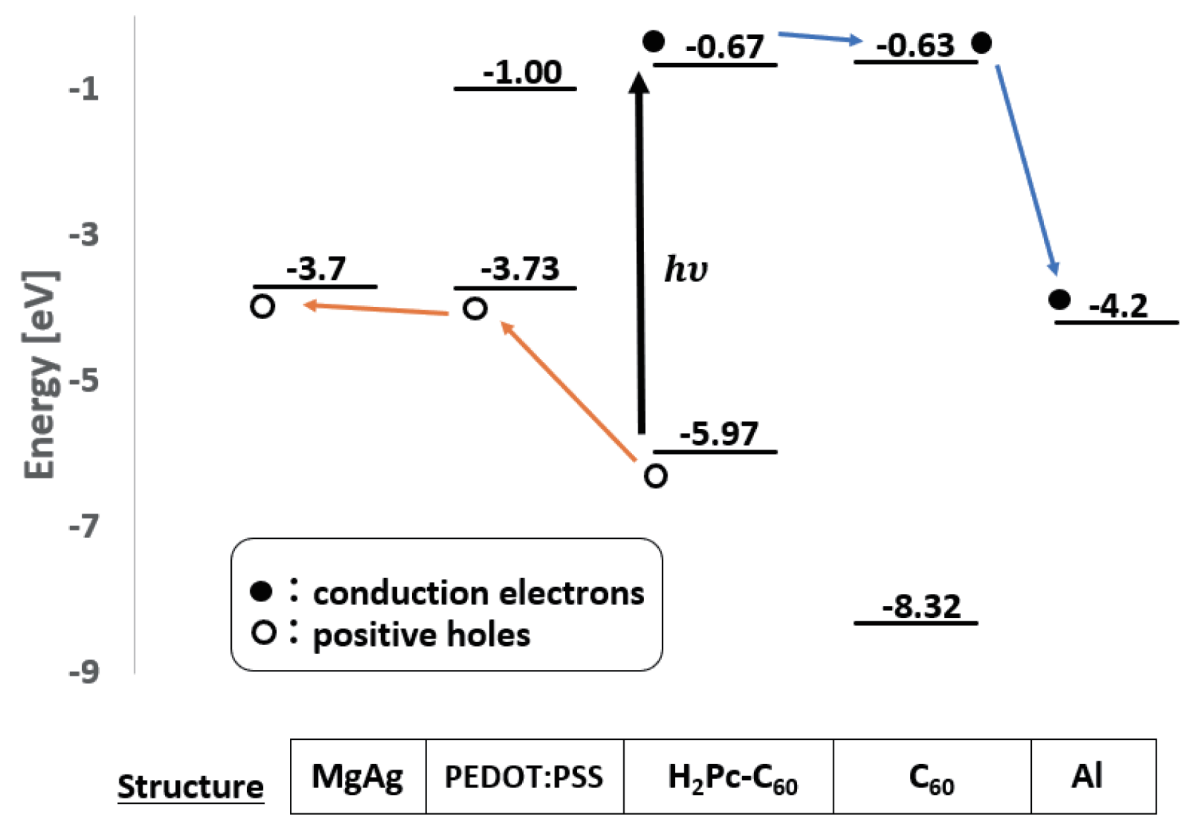

Figure 4. Energy diagram of organic solar cell devised

極から電流が取り出され発電される．伝導電子と正孔の 輸送経路は，本素子においては，それぞれ理想的な階段 状のエネルギー準位となっていることがわかる.

\section{4 まとめ}

我々は, PEDOT:PSS, $\mathrm{H}_{2} \mathrm{Pc}$ と $\mathrm{C}_{60}$ を用いた有機太陽電 池を考案した. 本系は, 基底状態, 励起状態共に伝導電 子と正孔の発生が量子化学計算より見込まれる.電極 は，MgAg と Alを採用した。 エネルギーダイアグラムは 理想的な階段構造となっている.

\section{謝辞}

本研究は，学術研究助成基助成金基盤研究 C（一般） 20K04633の助成を受けたものである.

\section{参考文献}

[1] M. Hiramoto,, , Ohyo Butsuri, 77, 539 (2008).

[2] T. T. T. Luong, et al., Sol. Energy Mater. Sol. Cells, 94, 1059 (2010). DOI:10.1016/j.solmat.2010.02.023

[3] http://cs2.toray.co.jp/news/toray/newsrrs01.nsf/0/C1DDF 5A8F7C308B149257D0F002F28EF

[4] L. Meng, Y. Zhang, X. Wan, C. Li, X. Zhang, Y. Wang, X. Ke, Z. Xiao, L. Ding, R. Xia, H. L. Yip, Y. Cao, Y. Chen, Science, 361, 1094 (2018). DOI:10.1126/science. aat2612, PMID:30093603

[5] W. Zhao, S. Li, H. Yao, S. Zhang, Y. Zhang, B. Yang, J. Hou, J. Am. Chem. Soc., 139, 7148 (2017). DOI:10.1021/ jacs.7b02677, PMID:28513158

[6] H.Matsumoto e, al., Fiber Preprints, Japan, 71(2016),No.2(Autumn Meeting), p55

[7] Y. Ikenaga, K. Narushima, K. Mitsui, J. Comput. Chem. Jpn., 16, 144 (2017). DOI:10.2477/jccj.2017-0064

[8] K. Narushima, J. Comput. Chem. Jpn., 17, 219 (2018). DOI:10.2477/jccj.2018-0064

[9] M. Honda, K. Narushima, J. Comput. Chem. Jpn., 13, 210 (2014). DOI:10.2477/jccj.2013-0027

[10] T. Yamaguchi, et al., J. Imaging Soc. Jpn., 54, 611 (2015). 